\title{
Facts and Reflections on Initial Public Health Emergency Response to SARS and COVID-19 Pandemics in Mainland China: A Retrospective Comparative Study
}

\author{
Huanhuan Zhu \\ Fudan University \\ Qian Wang \\ Fudan University \\ Tiantian Zhang \\ Fudan University \\ Xin Liu \\ Fudan University \\ Ruiming Dai \\ Fudan University \\ Ping Wu \\ Fudan University \\ Ge Bai \\ Fudan University \\ Ying Wang \\ Fudan University \\ Ping Zhou \\ Fudan University \\ Li Luo ( liluo0519@163.com ) \\ Fudan University
}

Research article

Keywords: Severe Acute Respiratory Syndrome (SARS), Coronavirus disease-2019 (COVID-19), emerging infectious diseases, public health emergency, emergency response

Posted Date: July 21st, 2020

DOI: https://doi.org/10.21203/rs.3.rs-40308/v1

License: () (1) This work is licensed under a Creative Commons Attribution 4.0 International License. Read Full License 


\section{Abstract}

Background: Since December 2019, 2019-nCoV has emerged in Wuhan, China, the fast pace of transmission is wreaking global public health crisis. Country's reaction speed is critical for the control of public health emergency (PHE), especially in the early stage of an outbreak. Compared with SARS pandemic, whether has the efficiency of initial public health emergency response to COVID-19 in mainland China been improved? And whether is there still existing vulnerabilities in current PHE system? Studies on this topic are relatively few. We tried to find the answers, evidences and alternatives.

Methods: We conducted a retrospective comparative study. The speed of hospital reporting, pathogen identification and government decision-making between SARS and COVID-19 were compared by selecting 5 critical events from initial public health emergency response timeline. Besides, combining with the two pandemics' progress curves, we discussed the characteristics of their peak time.

Results:(1) SARS completed the entire initial public health emergency response in 127 days, and COVID-19 completed in 44 days. Response speed has been shorted nearly by 3 times. (2) Both the first SARS and COVID-19 cases were reported in 19 days. It doesn't appear that hospital reporting speed becomes faster. (3) The accumulated time completing pathogen identification were 118 days for SARS and 31 days for COVID-19. The speed has been improved by more than 3 times. (4) 9 days after the completion of pathogen identification, national government made emergency policies for SARS while the interval between pathogen identification and national government's decision-making for COVID-19 was 13 days. (5) The peak time of SARS came about 80 days later than that of COVID-19. But both the two pandemics' peak occurred about 20 days after the national government's decision-making, and then the curves went down dramatically.

Conclusions: The speed of initial public health emergency response to pandemic has been improved due to faster identification. However, some deficiencies and challenges in early alert and authorities' decision-making still remain. Therefore, Chinese government should put more stress on improving hospital's sensitivity to new emerging infectious diseases and timeliness of government's decisionmaking.

\section{Background}

The current outbreak of COVID-19, which emerged in Wuhan, China, in late December 2019, has spread all over the world and brought up a severe global public health crisis [1, 2]. On 11 March 2020, the World Health Organization (WHO) declared COVID-19 a pandemic [3]. And there has been more than 7 million confirmed cases and 408,025 deaths reported worldwide up to 10 June 2020[4]. Besides, to fight for this pandemic, a US\$675 million preparedness and response plan has been launched $[5,6]$. All of these illustrates the severity of this pandemic.

There has been one previous severe outbreak of novel coronavirus-SARS in 2003, which occurred in Guangdong, China, and gave rise to the first pandemic of the 21 st century. The two coronaviruses have similarities. For example, they have remarkable genomic resemblance, and the diseases caused by them are transmissible from person to person [7]. Yet as the latest infectious respiratory disease, COVID-19 has a higher rate of transmissibility-whose basic reproductive number $\left(R_{0}\right)$ ranging from 2.2 to 6.47 is higher than the $R_{0}$ of SARS (1.7-1.9), making it much more difficult to treat [8-12]. Consequently, public health efforts are expected to have a substantial impact on reducing the size of the pandemic and instilling a sense of reassurance to the population. At this point, timely suppression measures from local authorities especially in the early stage of the outbreak will be crucial to blunt the severity of the pandemic and save lives $[13,14]$.

The more secure and stable a public health emergency system is, the better prepared one nation will be to handle possible outbreak. SARS maximally challenged the capacity of the old Chinese PHE system and identified critical limitations, such as unpreparedness for public emergencies, lack of effective surveillance, poor communication, and so on [15]. All these deficiencies led to the low inefficiency of Chinese government's reaction in the course of combating with the SARS pandemic. Since then, a comprehensive reform from Chinese government was employed to improve its PHE system. In order to promptly and effectively deal with various emerging infectious diseases, China established a unified PHE management system through legislation, gave priorities to the development of biotechnology industrialization (especially in the areas of pathogen identification), and increased investment in direct reporting system of infectious diseases' establishment [16]. In this perspective, COVID-19 pandemic is not only a new challenge to Chinese government, but also a check on the effectiveness of the new emergency response system. 
Compared with SARS pandemic, whether has the efficiency of initial public health emergency response to COVID-19 in mainland China been improved? And whether is there still existing vulnerabilities in current PHE system? The existing literatures mostly focus on the estimation of basic reproduction ratio [8] and risk for death [17], features of patients [18-20], and studies on the comparison of government's response between SARS and COVID19 are relatively few. Therefore, we generalized the changes and evaluated whether improvements had been made mainly by comparing the speed of initial emergency response to SARS and COVID-19 in mainland China. Based on the official published announcements and combined with the comparison results, we tried to explore the still existing failures and successes related to the current PHE system and give solutions and alternatives for new outbreaks in the future.

\section{Methods}

\section{Critical events selection and study design}

The process of government's emergency response to pandemic is chronological, which generally includes monitoring, discovery, investigation, intervention and recovery stages. So, we defined the series of measures and actions implemented to monitor, identify, conform and contain the pandemic before the pandemic's exponential growth trend as the initial public health emergency response.

We selected-the first reported cases, hospital reporting to local authorities, isolation of the pathogen, completion of the gene sequencing, national government's decision-making-these 5 events, as the critical time nodes from the total timeline of initial public health emergency response. And the whole process was divided into three phrases, namely, hospital reporting, pathogen identification and government's decision-making. The reasons why we chose these time points to evaluate are as follows.

Firstly, when pandemic occurs, hospital medical staff are usually the first responders and information providers. Therefore, we chose the time of first reported case and hospital reporting as the first two nodes to evaluate the hospital and medical staff's sensitivity to new emerging infectious diseases. Secondly, it is important for public health agencies, health care providers, and the public to be aware of new coronavirus so that coordinated, timely, and effective actions can help prevent additional cases or poor health outcomes. The early recognition of cases and understanding of the virus, including its transmission and severity, can be used to inform national and global response action. So, we selected the time of isolation of pathogen and acquisition of genome sequence as the two nodes in pathogen identification phrase. Finally, the efficiency of government policy taken in relation to preparedness and responsiveness to pandemics. The earlier the government decision-makers make the reaction, the more favorable the pandemic prevention and control work. Hence, we chose the time of national government's implementation of emergency policies as the key node in the government decision-making phrase. Taking the time of the first reported cases as the baseline time point, we calculated the interval and accumulated days of each node and each phrase. And the results were applied to compare the speed of hospital reporting, pathogen identification and government's decision-making between two pandemics.

Besides, combining with the two pandemics' progress curves, we compared and discussed the characteristics of their peak time.

\section{Data Collection}

The information about 5 key time nodes for SARS were collected from the academic literatures, reports from WHO, memorabilia remained on Chinese Center for Disease Control and Prevention (Chinese CDC) website, official announcements from the State Council Information Office of the People's Republic of China and Information Office of Guangdong Government, and XINHUANET. The information about 5 key time nodes for COVID-19 were collected from the academic literatures, reports from WHO, announcements from Wuhan Municipal Health Commission, Hubei Government, Health Commission of Hubei Province and National Health Commission and XINHUANET.

SARS cases data in mainland China came from academic articles, the announcements of the Information Office of Guangdong Government and the Ministry of Health of China. COVID-19 cases data in mainland China came from DXY.cn. 
Table 1

Timeline of initial public health emergency response to SARS and COVID-19

\begin{tabular}{|c|c|c|c|c|c|c|c|}
\hline \multirow[t]{2}{*}{ Phrases } & \multirow[t]{2}{*}{ Key time nodes } & \multicolumn{3}{|l|}{ SARS } & \multicolumn{3}{|l|}{ COVID-19 } \\
\hline & & Events & Dates & $\begin{array}{l}\text { Accumulated } \\
\text { days }\end{array}$ & Events & Dates & $\begin{array}{l}\text { Accumulated } \\
\text { days }\end{array}$ \\
\hline \multirow[t]{2}{*}{$\begin{array}{l}\text { Hospital } \\
\text { reporting }\end{array}$} & $\begin{array}{l}\text { Firs reported } \\
\text { cases }\end{array}$ & $\begin{array}{l}\text { First reported } \\
\text { patient } \\
\text { Xingchu } \\
\text { Huang was } \\
\text { received by } \\
\text { Heyuan } \\
\text { People's } \\
\text { Hospital. }\end{array}$ & $\begin{array}{l}15 \\
\text { December } \\
2002\end{array}$ & 1 & $\begin{array}{l}\text { The first novel } \\
\text { coronavirus } \\
\text { case in Wuhan } \\
\text { was } \\
\text { conformed. }\end{array}$ & $\begin{array}{l}8 \\
\text { December } \\
2019\end{array}$ & 1 \\
\hline & $\begin{array}{l}\text { Hospital } \\
\text { reported to } \\
\text { local } \\
\text { authorities }\end{array}$ & $\begin{array}{l}\text { Heyuan } \\
\text { People's } \\
\text { Hospital } \\
\text { reported to } \\
\text { the Health } \\
\text { Department } \\
\text { of } \\
\text { Guangdong } \\
\text { Province. }\end{array}$ & $\begin{array}{l}2 \text { January } \\
2003\end{array}$ & 19 & $\begin{array}{l}\text { Wuhan } \\
\text { Integrated } \\
\text { Traditional } \\
\text { Chinese and } \\
\text { Western } \\
\text { Medicine } \\
\text { Hospital } \\
\text { reported to } \\
\text { local CDC. }\end{array}$ & $\begin{array}{l}26 \\
\text { December } \\
2019\end{array}$ & 19 \\
\hline \multirow[t]{2}{*}{$\begin{array}{l}\text { Pathogen } \\
\text { identification }\end{array}$} & $\begin{array}{l}\text { Isolation of } \\
\text { virus }\end{array}$ & $\begin{array}{l}\text { The novel } \\
\text { coronavirus } \\
\text { was isolated } \\
\text { by Chinese } \\
\text { CDC's } \\
\text { experts. }\end{array}$ & $\begin{array}{l}11 \text { April } \\
2003\end{array}$ & 118 & $\begin{array}{l}\text { The novel } \\
\text { coronavirus } \\
\text { was isolated } \\
\text { from the } \\
\text { patients' } \\
\text { specimens by } \\
\text { Chinese CDC's } \\
\text { experts. }\end{array}$ & $\begin{array}{l}7 \text { January } \\
2020\end{array}$ & 31 \\
\hline & $\begin{array}{l}\text { Acquisition of } \\
\text { virus genome } \\
\text { sequence }\end{array}$ & $\begin{array}{l}\text { The isolated } \\
\text { coronavirus' } \\
\text { genome } \\
\text { sequence } \\
\text { was also } \\
\text { obtained by } \\
\text { Chinese } \\
\text { CDC's } \\
\text { experts. }\end{array}$ & $\begin{array}{l}11 \text { April } \\
2003\end{array}$ & 118 & $\begin{array}{l}\text { The isolated } \\
\text { coronavirus's } \\
\text { genome } \\
\text { sequence was } \\
\text { also obtained } \\
\text { by Chinese } \\
\text { CDC's experts. }\end{array}$ & $\begin{array}{l}7 \text { January } \\
2020\end{array}$ & 31 \\
\hline $\begin{array}{l}\text { Government's } \\
\text { decision- } \\
\text { making }\end{array}$ & $\begin{array}{l}\text { Implementation } \\
\text { of national } \\
\text { government's } \\
\text { PHE policies }\end{array}$ & $\begin{array}{l}\text { National } \\
\text { government } \\
\text { began to take } \\
\text { stringent } \\
\text { control } \\
\text { measures, } \\
\text { such as } \\
\text { listing SARS } \\
\text { as a legal } \\
\text { infectious } \\
\text { disease, } \\
\text { implementing } \\
\text { mandatory } \\
\text { reporting of } \\
\text { SARS and } \\
\text { reporting by } \\
\text { the national } \\
\text { media etc. }\end{array}$ & $\begin{array}{l}20 \text { April } \\
2003\end{array}$ & 127 & $\begin{array}{l}\text { Chinese } \\
\text { national } \\
\text { government } \\
\text { made a } \\
\text { request to do } \\
\text { its best to } \\
\text { prevent and } \\
\text { control the } \\
\text { COVID-19 } \\
\text { pandemic and } \\
\text { COVID-19 was } \\
\text { included in } \\
\text { notifiable } \\
\text { infectious } \\
\text { diseases by } \\
\text { National } \\
\text { Health } \\
\text { Commission's } \\
\text { announcement } \\
\text { No.1 }\end{array}$ & $\begin{array}{l}20 \\
\text { January } \\
2020\end{array}$ & 44 \\
\hline
\end{tabular}

\section{Results}

First, the timeline of initial public health emergency response to the two pandemics were elaborated in Table 1. Then after collecting the cases data of SARS and COVID-19, we drew their pandemic curves (Fig. 1 and Fig. 2) in combination with initial public health emergency response timeline. Moreover, the comparison results of speed in three phrases were displayed by Fig. 3 . The details and related facts are as follows. 


\section{Phrase Of Hospital Reporting}

SARS: The earliest case occurred in 16 November 2002, Foshan first people's hospital [21]. As a result of the lack of awareness of SARS by health workers and the absence of functional infectious diseases surveillance system(the traditional surveillance network using reporting cards filled out by hand and sent by mail or fax [22]) at that time, the hospital could neither identify the potential risk nor report to local CDC or authority right away[23, 24]. Later, Heyuan People's Hospital admitted one patient named Xingchu Huang on 15 December 2002. When the atypical pneumonia of unknown cause began appearing among hospital staff, the hospital realized the seriousness and reported to the Health Department of Guangdong Province on 2 January 2003[21, 25]. Because Mr. Huang was identified as the first reported case of SARS in China, we set the starting point of the initial public health emergency response to SARS pandemic on 15 December 2002(Fig. 1, Point $邓$ ). Thus, the duration of hospital reporting was 19 days(Fig. 1, Point $邓$ ).

COVID-19: Since April 2004, the report of infectious diseases has been changed from the previous monthly report by administrative units to the direct report by the network of medical institutions [22, 26]. However, in the early stage of COVID-19 pandemic, it seemed the direct reporting system did not have its expected function. On 31 December 2019, WHO China Country Office was informed of "Pneumonia of unknown cause" [27]; Yet weeks earlier, Wuhan authorities had been warned by healthcare professionals that a SARS-like illness was spreading amongst patients. Unfortunately, they chose to detain them on a charge of spreading false rumors instead of reporting to superior authorities [28, 29]. On 11 January 2020, Wuhan Municipal Health Commission reported in the media that the first COVID-19 case was diagnosed on 8 December 2019 in Wuhan Integrated Traditional Chinese and Western Medicine Hospital[30] ( Fig. 2, Point 8 ). And local CDC was informed by Doctor Zhang on 26 December 2019[31], which means the duration of hospital reporting was also 19 days(Fig. 2, Point $\triangle$ ).

\section{Phrase Of Pathogen Identification}

SARS: It was the first time for China to tackle the PHE caused by unknown virus. Due to the fragmentation of health research system and the deficiencies of coordination and cooperation amongst the research institutions, the process of pathogen identification was inefficiency. Chinese scientific and research institutions and their personnel had misjudged that "the pathogen can be basically identified as Chlamydia", which caused the missing of chance to constrain the pandemic [32]. With the international collaboration of 13 laboratories from 10 countries and regions, the cause of SARS was confirmed finally [33]. On 22 March 2003, Peris and his colleagues from Hong Kong University took the lead in announcing the successful isolation of the new coronaviruses from patient samples [34, 35]. On 12 April 2003, Michael Smith Genome Science Center of Canada completed the whole genome sequence of the SARS-associated coronavirus and released the world's first genetic map of SARS coronavirus [36]. As for China, according to the memorabilia retained on the website of Chinese CDC, experts of Virus Research Institute isolated the virus and completed the genome sequence on April 11[37]. Given the study focusing on the emergency response of China, we adopted the time from Chinese CDC, considering the principle of comparability. Therefore, the accumulated time of the completion of pathogen identification from the first reported cases was 118 days(Fig. 1, Point $\& \bigotimes)$.

COVID-19: According to the news from XINHUANET, on 7 January 2020, the novel coronavirus was isolated from the patients' specimens, and genome sequence were obtained by Chinese CDC's experts at the same day [38]. So, the accumulated time of the pathogen identification from the first reported case was 31 days(Fig. 2, Point $₫ \&$ ).

\section{Phrase Of Government Decision-making}

SARS: SARS pandemic curve shows two surging trends (see Fig. 1)-first in Guangdong, and later in Beijing, which partly due to the limited information transfer, the public knew little about what happened and the disease spread unnoticed at the beginning and then expanded rapidly. Until central government realized the severity of SARS pandemic, it began to issue series of policies to curb the spread, such as listing SARS as a tailored infectious disease, implementing mandatory reporting, and publishing definition of diagnostic criteria and treatment on 20 April 2003[39]. Consequently, national government's decision-making was after the completion of pathogen identification and its accumulated time from the first reported cases was up to 127 days(Fig. 1, Point囚). Ruling authorities' intervention came obviously late and cases of infection had taken off for a long time.

COVID-19: On 20 January 2020, Chinese central government made a request to prevent and control the COVID-19 pandemic [40], and COVID-19 was included in notifiable infectious diseases by National Health Commission's announcement No.1[41]. So, the accumulated 
time from the first reported cases to national emergency response was 44 days(Fig. 2, Point $邓$ ). And two days later, on 22 January 2020 , Hubei government launched the secondary emergency response plan (level II) [42].

\section{Peak Time Of Sars And Covid-19}

SARS: As the Fig. 1 showed, the new confirmed cases of SARS reached to the peak point of 2883 at 147 days (10 May 2003) after the outbreak and then went down markedly. There were no growth trends in the following three months. And the interval between the completion of initial public health emergency response and the arrival of peak was about 20 days.

COVID-19: As could be seen in the Fig. 2, the new confirmed COVID-19 cases reached the peak point of 15151 at 67 days (12 February 2020) after the outbreak. In the following months, the number declined dramatically and gradually entered into the plateau period. The climbing trends during plateau period were sporadic. In addition, the interval between the completion of initial public health emergency response and the arrival of peak was about 23 days.

\section{Discussion}

As we mentioned previously, China has made great efforts to establish a new mechanism for responding to emerging communicable diseases. Legislation is the main action, such as amending Law of People's Republic of China on Prevention and Control of Infectious Diseases and formulating Regulation on Emergency Response to Public Health Emergencies. Through these law, regulation and protocols, the legal responsibilities of government, health administrative departments and medical institutions are stipulated. As for the response mechanism, a systematic process has also been defined. Any hospital or other medical institutions who detect the potential infectious diseases risk must report to its local health administrative department within 2 hours, and the local health administrative department has to report to local government department within 2 hours and report to the superior authorities at the same time. Besides, the local and national authorities must organize experts to conduct a comprehensive assessment of the emergency including pathogen identification and epidemiological investigation so as to make the decision on whether and which level to launch the emergency plan $[43,44]$. It is one of the important premises that the process of initial public health emergency response to COVID-19 pandemic seemed to be more standardized.

On the whole, the relative speed of the COVID-19 response has improved greatly compared to the SARS response. The duration of initial public health emergency response has shortened from 127 days to 46 days. This mainly benefits from the significant improvement in the speed of pathogen identification. It only took 31 days to identify the pathogen in 2020, whose speed of identification has been improved nearly by 4 times compared with that in 2003.

However, the preparedness of PHE system still not so functional. From the experience of controlling SARS, we have learned that the timely alert against new emerging infectious diseases is essential: Delaying the control measures by 1 week would have nearly tripled the pandemic size and would have increased the expected pandemic duration by several weeks [45]. Unfortunately, it seemed that Chinese failed to learn from the lesson. In the stage of hospital reporting, both SARS and COVID-19 consumed 19 days, which means the reporting speed hasn't been improved (Fig. 3). It might infer that medical staff could still possess limited awareness of appropriate response. Therefore, as the first responders and information providers, medical staff's sensitivity to infectious disease still should be strengthened by education and training periodically [46]. Besides, combined with the facts that Wuhan authorities' punishment on doctors who tried to send the alarm, the long duration of the reporting phrase might also denote us that the direct reporting system still exists vulnerabilities. And these weaknesses mainly caused by authorities' strong intervention. Fears of economic and political repercussions silenced officials themselves and they also chose to silence the medical professionals who could have sounded alarms and curb the spread earlier. Thus, it is essential for government to consider how to make the full use of direct network-reporting system and make it truly play the role in prediction and early warming.

Secondly, as is shown in Fig. 3, the interval from the completion of pathogen identification to national government's decision-making was 13 days for COVID-19 while 9 days for SARS, so the speed of national government's decision-making hasn't been improved, either. Nevertheless, in spite of the peak time of SARS came about 80 days later than that of COVID-19, both the two pandemics' peak time arrived about 20 days after the completion of initial public health emergency response and then the new confirmed cases dropped down quickly. In this light, national government's decision-making might be the most influencing factor in the course of combating with pandemics in mainland China. Because of the strong political commitment and a centrally coordinated response from the top ruling authorities, the pandemic spread progress could control easier [47]. Thus, the comparison results of the peak time of the two pandemics 
once again prove the importance of the promptness of national government's decision-making. However, quickly decision-making hinges on decisive leadership [29]. Risk-informed decision-making, especially during a pandemic, requires exceptional leadership that prioritizes rigorous approaches to producing high-quality data and then turning that evidence into action [48]. In this regard, we could explore new digital technologies to make full use of the information scattered in the incubation period of the pandemic, and cultivate decision makers to crisis management who can quickly recognize the risk of the pandemic and make scientific decisions in time [49].

\section{Limitations}

There are several limitations in this study. First, the speed of initial public health emergency is important to mitigate the subsequent size of pandemic. However, the fast spread is also closely affected by many other different parameters such as the epidemiological characteristics of the novel coronavirus itself, a country demographics, age distribution, testing, diagnostic and treatment capacities and so on. Therefore, simply using five-time nodes to calculate the speed of three critical phrases and using speed results as the evidence to evaluate the government's initial emergency response performance for halting the spread of pandemic is limited. So, our research mainly focuses on the speed changes and explore the potential deficiencies in current emergency response system in combination with the related facts. In addition, due to the lack of transparency of data in 2003, some data and information about SARS outbreak mainly integrated from academic articles, official news, websites and other international reports. Since we chose the source with relative high authority, so the results are credible.

\section{Conclusion}

The speed of initial public health emergency response to pandemic has been improved due to the faster identification. However, some deficiencies and challenges in early alert and authorities' decision-making still remain. Modelling data suggests that if action had been taken even a few days earlier, the subsequent spread of the virus could have been limited dramatically [50]. Therefore, Chinese government should put more stress on improving hospital's sensitivity to malignant infectious diseases, giving full play to the function of the direct net-work reporting system of infectious diseases and ensuring the timeliness of government's decision-making.

\section{Abbreviations}

PHE

Public Health Emergency;

SARS

Severe Acute Respiratory Syndrome;

COVID-19

Coronavirus Disease-2019;

$\mathrm{CDC}$

Center for Disease Control and Prevention;

WHO

World Health Organization

\section{Declarations}

\section{Ethics approval and consent to participate}

The study was approved by the Medical Research Ethics Committee at the School of Public Health of Fudan University. This study didn't involve human participants and there was no data collected from humans or animals. Consent to participate for patients were not applicable.

\section{Consent for publication}

Not applicable.

\section{Availability of data and materials}

The datasets used and/or analyzed during the current study are available from the corresponding author on reasonable request. 


\section{Competing interests}

The authors declare that they have no competing interests.

\section{Funding}

This study was funded by the National Natural Science Foundation of China (No. 71874033) and Key Project of Philosophy and Social Science Research of the Ministry of Education of China (No. 15JZD029). The funding bodies had no involvement in the study design, data collection, analysis and interpretation of data or the decision to submit for publication.

\section{Authors' contributions}

Professor LL designed the conception and structure of the study, and HZ wrote the article. QW, TZ interpreted and analyzed the data. XL, $\mathrm{RD}$ and PW collected the data. GB, YW and PZ provided extensive information about this research. All authors read and approved the final manuscript.

\section{Acknowledgements}

We are grateful to all of the participants for their collaboration in this study.

\section{References}

1. Hui DS, Azhar El, Madani TA, Ntoumi F, Kock R, Dar O, Ippolito G, Mchugh TD, Memish ZA, Drosten C, et al. The continuing 2019nCoV epidemic threat of novel coronaviruses to global health - The latest 2019 novel coronavirus outbreak in Wuhan, China. Int $J$ Infect Dis. 2020;91:264-6.

2. Lu H, Stratton CW, Tang YW. Outbreak of pneumonia of unknown etiology in Wuhan, China: The mystery and the miracle. J Med Virol. 2020;92(4):401-2.

3. WHO Director-General's opening remarks at the media briefing on COVID-19-11 March. 2020 https://www.who.int/dg/speeches/detail/who-director-general-s-opening-remarks-at-the-media-briefing-on-covid-19-11-march-2020 Accessed 17 June 2020.

4. Coronavirus disease (COVID-19) Situation Report-142 [https://www.who.int/docs/default-source/coronaviruse/situationreports/20200610-covid-19-sitrep-142.pdf?sfvrsn=180898cd_2] Accessed 17 June 2020.

5. US\$675 million needed for new coronavirus preparedness and response global plan [https:// Accessed 17 June 2020.

6. Arshad Ali S, Baloch M, Ahmed N, Arshad Ali A, Iqbal A. The outbreak of Coronavirus Disease 2019 (COVID-19)-An emerging global health threat. J Infect Public Health. 2020;13(4):644-6.

7. Paules $\mathrm{Cl}$, Marston HD, Fauci AS: Coronavirus Infections-More Than Just the Common Cold. JAMA 2020.

8. He W, Yi GY, Zhu Y. Estimation of the basic reproduction number, average incubation time, asymptomatic infection rate, and case fatality rate for COVID-19: Meta-analysis and sensitivity analysis. J Med Virol 2020.

9. Petrosillo N, Viceconte G, Ergonul O, Ippolito G, Petersen E. COVID-19, SARS and MERS: are they closely related? Clin Microbiol Infect. 2020;26(6):729-34.

10. Singhal T. A Review of Coronavirus Disease-2019 (COVID-19). Indian J Pediatr. 2020;87(4):281-6.

11. Harapan H, Itoh N, Yufika A, Winardi W, Keam S, Te H, Megawati D, Hayati Z, Wagner AL, Mudatsir M. Coronavirus disease 2019 (COVID-19): A literature review. J Infect Public Health. 2020;13(5):667-73.

12. Lipsitch M, Cohen T, Cooper B, Robins JM, Ma S, James L, Gopalakrishna G, Chew SK, Tan CC, Samore MH, et al. Transmission dynamics and control of severe acute respiratory syndrome. Science. 2003;300(5627):1966-70.

13. Lee A, Morling J. COVID19: The need for public health in a time of emergency. Public Health. 2020;182:188-9.

14. Kapata N, Ihekweazu C, Ntoumi F, Raji T, Chanda-Kapata P, Mwaba P, Mukonka V, Bates M, Tembo J, Corman V, et al: Is Africa prepared for tackling the COVID-19 (SARS-CoV-2) epidemic. Lessons from past outbreaks, ongoing pan-African public health efforts, and implications for the future. International journal of infectious diseases: IJID : official publication of the International Society for Infectious Diseases 2020, 93:233-236.

15. Qin L, Jeng H, Rakue Y, Mizota T. A deficient public health system as a contributing cause of Severe Acute Respiratory Syndrome (SARS) epidemic in mainland China. Southeast Asian J Trop Med Public Health. 2005;36(1):213-6. 
16. Wei P, Cai Z, Hua J, Yu W, Chen J, Kang K, Qiu C, Ye L, Hu J, Ji K. Pains and Gains from China's Experiences with Emerging Epidemics: From SARS to H7N9. Biomed Res Int. 2016;2016:5717108.

17. Mizumoto K, Chowell G. Estimating Risk for Death from Coronavirus Disease, China, January-February 2020. Emerg Infect Dis. 2020;26(6):1251-6.

18. Li J, Gong X, Wang Z, Chen R, Li T, Zeng D, Li M. Clinical features of familial clustering in patients infected with 2019 novel coronavirus in Wuhan, China. Virus Res 2020:198043.

19. Huang C, Wang Y, Li X, Ren L, Zhao J, Hu Y, Zhang L, Fan G, Xu J, Gu X, et al. Clinical features of patients infected with 2019 novel coronavirus in Wuhan, China. Lancet. 2020;395(10223):497-506.

20. Chen NS, Zhou M, Dong X, Qu JM, Gong FY, Han Y, Qiu Y, Wang JL, Liu Y, Wei Y, et al. Epidemiological and clinical characteristics of 99 cases of 2019 novel coronavirus pneumonia in Wuhan, China: a descriptive study. Lancet. 2020;395(10223):507-13.

21. Feng D, de Vlas SJ, Fang LQ, Han XN, Zhao WJ, Sheng S, Yang H, Jia ZW, Richardus JH, Cao WC. The SARS epidemic in mainland China: bringing together all epidemiological data. Tropical Med Int Health. 2009;14:4-13.

22. Wang L, Wang Y, Jin S, Wu Z, Chin DP, Koplan JP, Wilson ME. Emergence and control of infectious diseases in China. Lancet. 2008;372(9649):1598-605.

23. Zhong N. Management and prevention of SARS in China. Philos Trans R Soc Lond B Biol Sci. 2004;359(1447):1115-6.

24. Wang Z: Investigation on crisis management of public health by Chinese government-cases of SARS and HFMD. Master. Shanghai,China: Shanghai Jiaotong University; 2009.

25. Yin J. SARS events. Chinese Journal of Disease Control and Prevention 2003(03):176-181.

26. Cao WC, de Vlas SJ, Richardus JH. The severe acute respiratory syndrome epidemic in mainland China dissected. Infect Dis Rep. 2011;3(1):e2.

27. Pneumonia of unknown cause - China [https:///]Accessed 19 June 2020.

28. Petersen E, Hui D, Hamer DH, Blumberg L, Madoff LC, Pollack M, Lee SS, McLellan S, Memish Z, Praharaj I, et al. Li Wenliang, a face to the frontline healthcare worker. The first doctor to notify the emergence of the SARS-CoV-2, (COVID-19), outbreak. Int J Infect Dis. 2020;93:205-7.

29. Forman R, Atun R, McKee M, Mossialos E. 12 Lessons Learned from the Management of the Coronavirus Pandemic. Health Policy 2020.

30. The latest interpretation report of the viral pneumonia whose cause was unknown by experts http://wjw.wuhan.gov.cn/front/web/showDetail/2020011109036 Accessed 21 April 2020.

31. Decisions on rewarding Comrade Zhang Dingyu and Zhang Jixian for their great achievements http://www.hubei.gov.cn/hbfb/bmdt/202002/t20200206_2020365.shtml Accessed 21 April 2020.

32. Enserink M. SARS in China. China's missed chance. Science. 2003;301(5631):294-6.

33. Coronavirus never before seen in humans is the cause of SARS https://www.who.int/csr/sars/archive/2003_04_16/en/ Accessed 21 April 2020.

34. Peiris JSM, Lai ST, Poon LLM, Guan Y, Yam LYC, Lim W, Nicholls J, Yee WKS, Yan WW, Cheung MT, et al. Coronavirus as a possible cause of severe acute respiratory syndrome. Lancet. 2003;361(9366):1319-25.

35. SARS virus isolated, new diagnostic test producing reliable results https://www.who.int/csr/sars/archive/2003_03_22/en/ Accessed 21 April 2020.

36. Marra MA, Jones SJM, Astell CR, Holt RA, Brooks-Wilson A, Butterfield YSN, Khattra J, Asano JK, Barber SA, Chan SY, et al. The genome sequence of the SARS-associated coronavirus. Science. 2003;300(5624):1399-404.

37. Memorabilia of Chinese Center for Disease Control and Prevention in 2003 [http://www.chinacdc.cn/was5/web/detail? record=1\&primarykeyvalue=\%E6\%96\%87\%E6\%A1\%A3ID='8220'\&channelid=133539] Accessed 22 April 2020.

38. Preliminary progress in pathogen identification of unexplained viral pneumonia in Wuhan http://www.xinhuanet.com/politics/202001/09/c_1125438971.htm?baike Accessed 21 Aril 2020.

39. Gao Qiang's speech at the press conference of the State Council Information Office [http://www.scio.gov.cn/xwfbh/xwbfbh/wqfbh/2003/0420/Document/327414/327414.htm] Accessed 22 April 2020.

40. Premier Li Keqiang chaired the executive meeting of the State Council and further arranged the prevention and control plan for the novel coronavirus pneumonia epidemic http://www.gov.cn/premier/2020-01/20/content_5471058.htm Accessed 22 April 2020.

41. Announcement of the Health Commission of the People's Republic of China [http://.shtml] Accessed 22 April 2020. 
42. Announcement of strengthening the prevention and control work of the novel coronavirus pneumonia epidemic http://www.hubei.gov.cn/xxgk/gsgg/202001/t20200122_2013895.shtml Accessed 22 April 2020.

43. Law on Prevention and Control of Infectious Diseases. In. China: The National People's Congress of the People's Republic of China; 2004.

44. Regulation on Emergency Response to Public Health Emergencies. In: 376. China; 2003.

45. Wallinga J, Teunis P. Different epidemic curves for severe acute respiratory syndrome reveal similar impacts of control measures. Am J Epidemiol. 2004;160(6):509-16.

46. Li X, Huang J, Zhang H. An analysis of hospital preparedness capacity for public health emergency in four regions of China: Beijing, Shandong, Guangxi, and Hainan. BMC Public Health. 2008;8:319.

47. de Vlas SJ, Feng D, Cooper BS, Fang LQ, Cao WC, Richardus JH. The impact of public health control measures during the SARS epidemic in mainland China. Trop Med Int Health. 2009;14(Suppl 1):101-4.

48. Watson C, Mullen L. Risk-Informed Decision Making: More Critical Today Than Ever Before. Health Secur 2020.

49. Deitchman S. Enhancing crisis leadership in public health emergencies. Disaster Med Public Health Prep. 2013;7(5):534-40.

50. Panovska-Griffiths J, Grieco L, van Leeuwen E, Baguelin M, Pebody R, Utley M. Are we prepared for the next influenza pandemic? Lessons from modelling different preparedness policies against four pandemic scenarios. J Theor Biol. 2019;481:223-32.

\section{Figures}

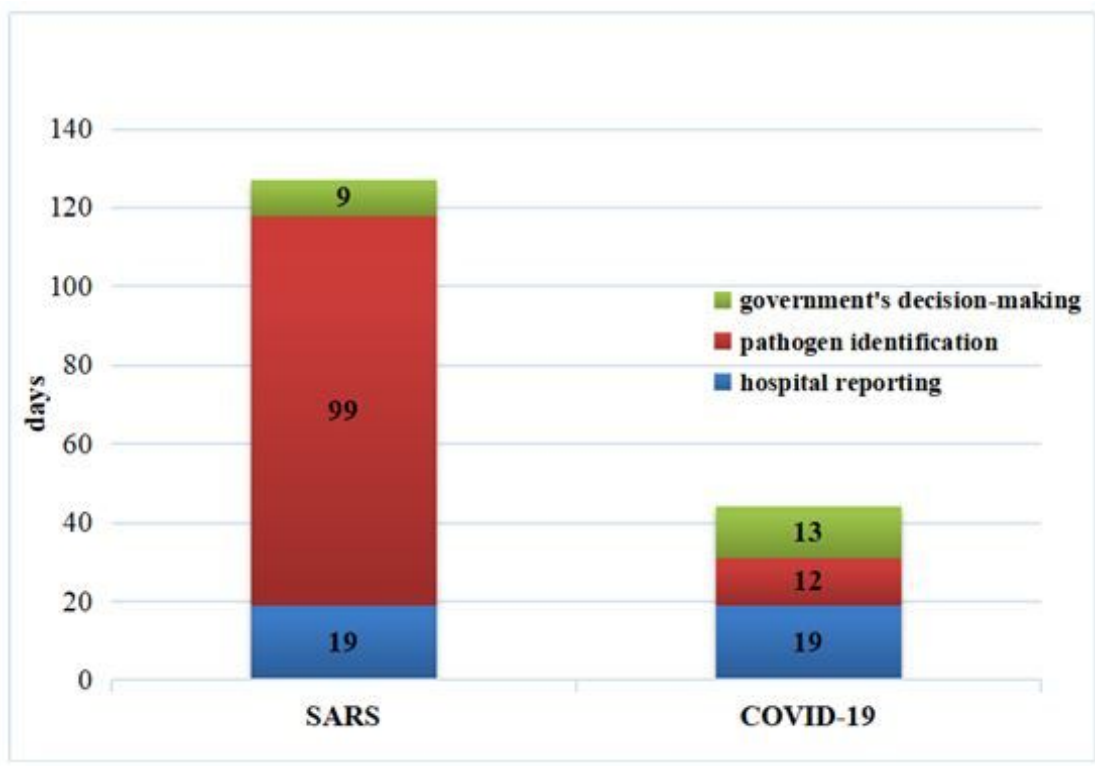

\section{Figure 1}

The Initial Public Health Emergency Response and progress of SARS Pandemic 


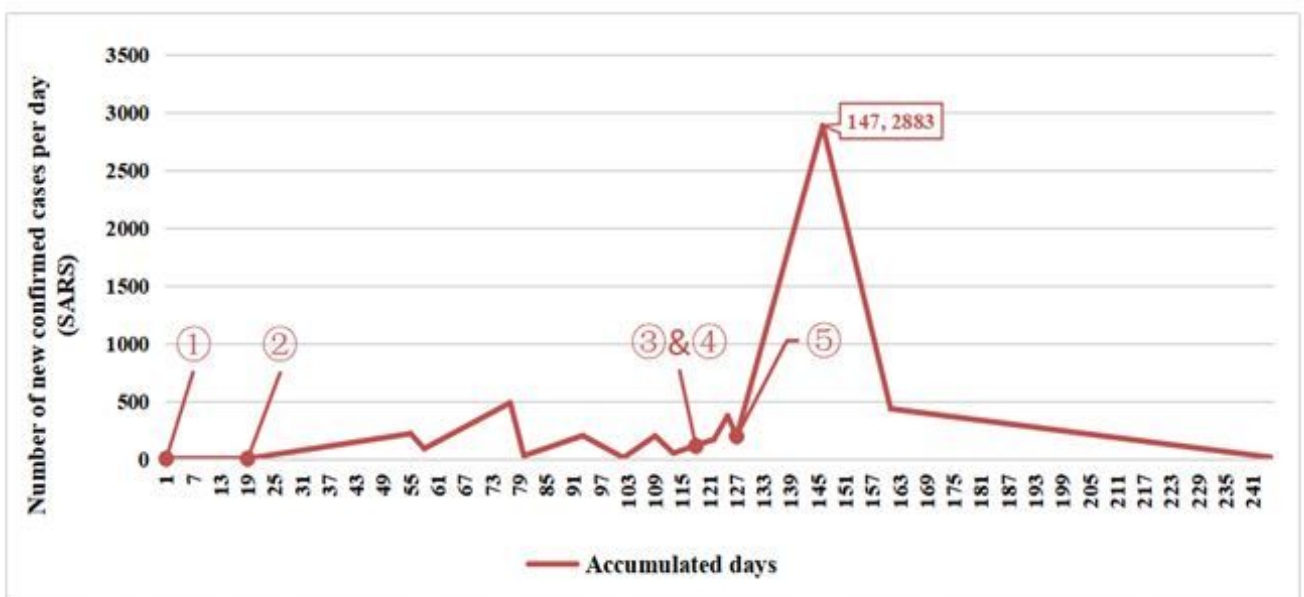

Note: Points reflect the accumulated days of key events and the number of new confirmed cases on that day: (1)First reported cases (2)Hospital reported to local authorities (3)Isolation of virus (4) Acquisition of virus genome sequence (5) Implementation of national govemment's PHE policies.]

\section{Figure 2}

The Initial Public Health Emergency and progress of COVID-19 Pandemic

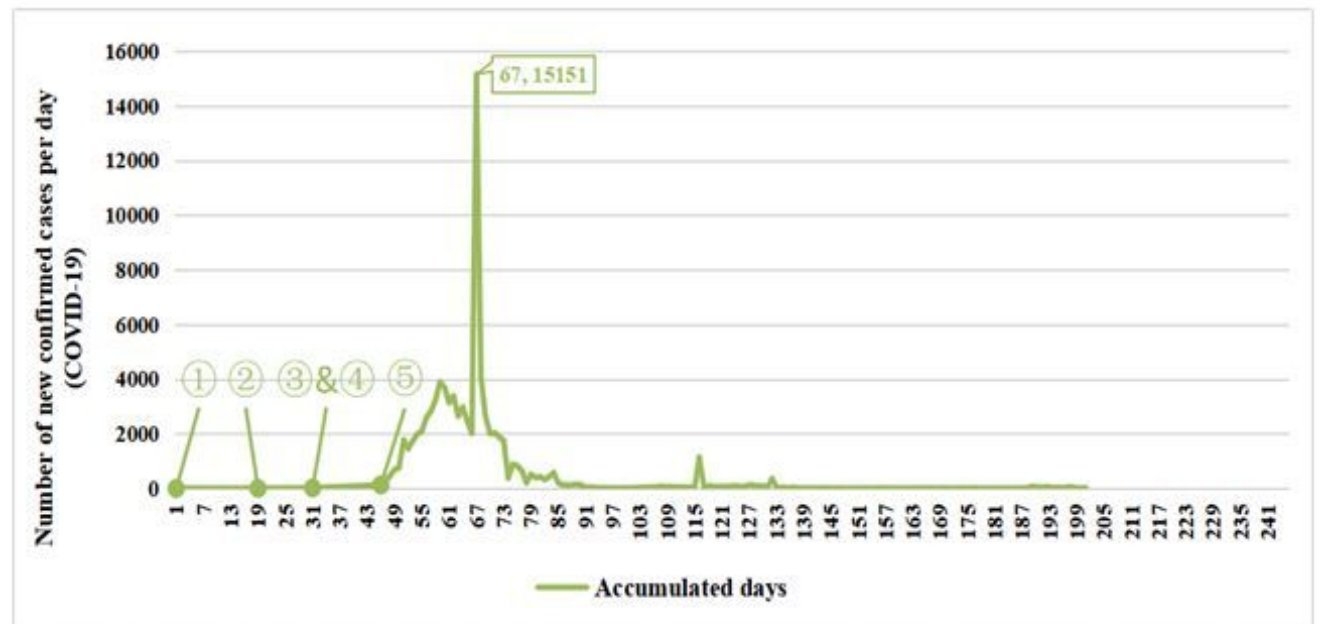

Note: Points reflect the accumulated days of key events and the number of new confirmed cases on that day: (1)First reported cases (2)Hospital reported to local authorities (3)Isolation of virus (4) Acquisition of virus genome sequence (5) Implementation of national govemment's PHE policies.

\section{Figure 3}

Response speed of SARS and COVID-19 in three phrases 